\title{
SIEVIETES RĪGAS POLITEHNISKAJĀ INSTITŪTĀ 20. GADSIMTA SĀKUMĀ
}

\section{ALĪDA ZIGMUNDE*,}

Rīgas Tehniskā universitāte

Kopsavilkums. 1862. gadā dibinātajā Rīgas Politehniskajā skolā (Rīgas Politehnikumā) sievietes nevarēja studēt, arī mācībspēki ilgus gadus bija tikai vīrieši, jo kopš viduslaikiem tāda bija universitāšu tradīcija. 1896. gadā augstskolu reorganizēja par Rīgas Politehnisko institūtu (RPI), un 1898. gadā darbā tika pieñemta pirmā darbiniece sieviete Helēna Valdmane. Viṇa strādāja kancelejā, un 20. gadsimta sākumā viṇai pievienojās vēl citas sievietes. RPI bibliotēkā pirmā sieviete Marija Paukule sāka strādāt 1913. gadā, bet mācībspēku sastāvā pirmā sieviete Olga Luebedeva parādījās 1915./1916. m. g., kad augstskola darbojās evakuācijā Maskavā. Tā bija asistente Olga L Lebedeva. Pirmās studentes RPI tika uzñemtas 1917. gada 1. septembrī. Daḷa no pirmajām RPI studentēm absolvēja citas augstskolas, tostarp Latvijas Universitāti.

Atslēgas vārdi: sievietes - darbinieces, studentes, docētājas, Rīgas Politehniskais institūts.

21. gadsimtā sievietes inženierzinātnēs un tehniskajās augstskolās sastopamas ik uz soḷa, un dažās specialitātēs vinu îpatsvars līdzinās vīriešu skaitam. Tas ir feminizācijas rezultāts, un mūsdienās tā ir ikdiena, bet līdz 20. gadsimtam situācija bija citāda, tāpēc raksta mērksis ir atspoguḷot, kā veidojās priekšstati par sieviešu uzṇemšanu augstskolās un kā tas izpaudās senākajā augstskolā tagadējā Latvijā. Veidojot rakstu, kā pētniecības metode izmantota hermeneitika, veicot avotu un literatūras analīzi, kā arī biogrāfiskā pieeja. Rakstā ir

* Korespondējošais autors.

E-pasts: alida.zigmunde@rtu.lv 
izsekots sabiedriskās domas attīstībai par sievietes ienākšanu augstskolā, kas saistāms ar sieviešu emancipācijas kustības aizsākumiem 19. gadsimtā.

\section{Līdztiesība studijās un darbā - sieviešu emancipācijas rezultāts}

Atskatoties vēsturē, redzam, ka Rietumu civilizācijas kultūras tradīcijā par nozīmīgākām daudzus gadsimtus tika uzskatītas maskulīnās vērtības. Un sievietes mātes un mājsaimnieces pienākumi bija tradīcija, kas bija iesakn,ojusies kā femīnās vērtības mēraukla. 18. gadsimtā līdz ar Brāḷu draudzes ienākšanu Vidzemē sievietes stāvoklis sabiedrībā mainījās, un vinām tika dota iespēja līdzdarboties sabiedrības dzīvē [1] Veicinot lasīt un rakstītprasmi, samazinājās analfabētu skaits, tostarp sieviešu vidū. Mājmācībā bērni apguva pirmās zināšanas mātes vadībā. Sievietēm radās iespēja pašām lasīt bībeli, vēlāk - arī laikrakstus un grāmatas. Ar meiteṇu skolās iegūtajām zināšanām turpmākajā dzīvē sievietes naudu nepelnīja, taču līdzās saviem dzīvesbiedriem viṇu redzesloks un dzìves izpratne krietni paplašinājās. 19. gadsimtā pēc zemnieku brīvlaišanas un straujās industralizācijas ǵimenes galva - vīrietis - joprojām bija tas, no kura nopelnītā bija atkarīga ǵimenes finansiālā situācija. Ja gimenē bija vairāki bērni un nebija iespēju visiem nodrošināt labu izglītību, vecāki parasti izvēlējās izskolot kādu no dēliem.

Kad 1862. gada oktobrī Rīgas Tehniskās universitātes priekštece, Rīgas Politehniskā skola, ko parasti dēvēja par Rīgas Politehnikumu, sāka darbību, tajā strādāja un studēja tikai vīrieši, jo tāda bija gadsimtiem ilga tradīcija, un tā tika pārṇemta pirmajā Baltijas valstu tehniskajā augstskolā. Arī 19. gadsimta beigās, 1896. gadā, kad augstskolu reorganizēja par Rīgas Politehnisko institūtu (RPI), sievietēm tajā nebija ațlauts studēt. Rīgas Politehnikuma Padome un Mācību komiteja 1870. gadā apsprieda jautājumu par sieviešu kā brīvklausītāju pielaišanu, taču nolēma viṇas augstskolā neuzṇemt. Augstskolas Padomes locekḷi uzskatīja, ka sievietes var ienest akadēmiskajā dzīvē «nekārtības vai vēl ko l̦aunāku» [2]. Rīgas Politehnikuma profesora Aleksandra Beka (18471926) sieva Marija Beka (1855-1929) bieži iegriezās augstskolas ēkā tagadējā Raiṇa bulvārī 19, kur uz viṇu noskatījušies vīrieši, domājams, studenti. Marijai Bekai sev raidītie skati nav bijuši patīkami. Šādu faktu mēs uzzinām no Marijas Bekas brālim Emīlam, Štutgartes Politehnikuma studentam, 1880. gada 15. maijā rakstītās vēstules, kurā viṇa jautāja, vai viṇš redz profesoru sievas bez kautrēšanās staigājam pa augstskolu [3]. Situācija mainījās 19. gadsimta beigās un 20. gadsimta sākumā, kad sieviešu emancipācijas rezultātā arvien vairāk sieviešu mācījās ğimnāzijās, 
studēja Eiropas augstskolās un strādāja algotu darbu. Latvijas teritorijā darbojās vairākas sieviešu ǵimnāzijas, bet to absolventes varēja studēt ārzemēs vai mācīties dažādos kursos, lai iegūtu tiesības strādāt par skolotājām, bērnudārzu audzinātājām un citās profesijās. Toreiz sieviete ar gimnāzijas izglìtību faktiski bija sasniegusi savas izglīīibas augstāko pakāpi. Izglītotas sievietes prestižs bija pieaudzis latviešu sabiedrībā [4], kā arī citu tautību vidū. 19. gadsimta beigās sievietes varēja iegūt Rīgā arodskolas izglītību atsevišksās «sieviešu» profesijās (aukles, šuvējas u. c.). Dažas kurzemnieces un vidzemnieces studēja Šveicē un citviet, iegūstot ārstes, filozofes un citus diplomus. Kurzemes guberṇā 1897. gadā dzīvoja 23 sievietes, kuras bija apmeklējušas universitātes, kā arī divas sievietes, kas bija mācījušās augstākajās tehniskajās vai speciālajās skolās [5]. Lai gan sieviešu ārzemju augstskolās 19. gadsimta beigās un 20. gadsimta sākumā bija krietni mazāk nekā vīriešu, sieviešu izglītošanai arvien lielāku uzmanību pievērsa sabiedrība. Zināms, ka 1889. gadā Oksfordas Universitātē par mācībspēku tiesību zinātnēs kḷuva Kornelija Sorabji (1866-1954) - indiešu izcelsmes advokāte. Rīdzinieki šādam solim toreiz vēl nebija gatavi, un vietējā augstskolā, Rīgas Politehnikumā, varēja studēt tikai vīrieši. Lai gan sieviešu emancipācija bija neizbēgama un to atzina latviešu prese, jautājums par sievietes pilnīgu emancipāciju tika atrisināts tikai 20. gadsimtā [5].

Rīgas Tehniskās universitātes (RTU) un Latvijas augstskolu vēsturē 2017. gads saistās ar neparastu jubileju - tieši pirms 100 gadiem, 1917. gada 1. septembrī, toreizējā Rīgas Politehniskā institūta studentu pulkā tika uzṇemtas pirmās sievietes. Tikai 1958. gadā pirmā sieviete tika ievēlēta dekānes amatā atjaunotajā RPI - docente, latviešu k̦īmiḳe Emīlija Gudriniece. Jāatzīmē, ka pēc Otrā pasaules kara Latvijas Valsts universitātes Kīmijas fakultātes dekānes kopš 1945. gada bija vairākas sievietes. RTU 155. gadadienu sagaidām ar divām fakultāšu dekānēm: profesori Marinu Platonovu, ETHZF dekāni kopš 2014. gada, un profesori Elīnu Gaili-Sarkani, IEVF dekāni kopš 2017. gada. Patlaban augstskolā sievietes gan studē, gan strādā dažādos amatos.

\section{Sievietes - RPI darbinieces un docētājas}

Par sievietēm darbiniecēm un mācībspēkiem Rīgas Politehniskajā institūtā liecina arhīvu un bibliotēku krātuvēs saglabājušās liecības, kas izmantotas šì raksta sagatavošanā. Pirmā sieviete, kas sāka strādāt Rīgas Politehniskajā institūtā, bija Helēna Valdmane (1873-pēc 1944). Viṇa 1898. gada 1. aprīlī sāka strādāt RPI kancelejā līdzās vīram Aleksandram Valdmanim. Helēna Valdmane strādāja RPI līdz tā slēgšanai 1919. gada augustā un tūdal turpināja darbu kā vecākā kancelejas 
darbiniece jaundibinātajā Latvijas Augstskolā (no 1923 - Latvijas Universitātē), kur strādāja līdz 1941. gada 1. janvārim [6]. 1910. gada 1. februārī RPI direktora kancelejā darbu sāka Margrieta Akermane (1887-1972) [7], kuras karjera bija līdzīga - arī vinas vīrs Eduards Akermanis strādāja augstskolas kancelejā. Taču Margrieta un Eduards Akermaṇi no Krievijas, kur Pirmā pasaules kara gados bija evakuēts RPI, atgriezās tikai 1920. gadā un darbu Latvijas Augstskolā abi sāka vēlāk nekā Valdmaṇu gimene. Sievietēm neuzticēja kancelejas vadību, to veica vīrieši. Tomēr jau 1914./1915. akadēmiskajā gadā aptuveni viena trešdaḷa RPI direktora kancelejas darbinieku bija sievietes - Helēna Valdmane, Margrieta Akermane un Ilona Krieviṇa [8]. Darbu LU kancelejā turpināja arī Ilona Krievin,a, kas pēc apprecēšanās pazīstama kā Ilona Dumpe (1891-1962) [9]. Minēto trīs sieviešu darbs, kas sākās RPI kancelejā un turpinājās LU sienās, tika augstu novērtēts - viṇas saṇēma valdības apbalvojumus. 1934. gadā Helēna Valdmane un Margrieta Akermane tika apbalvotas ar V šķiras Triju Zvaigžṇu ordeni, bet Ilona Dumpe ar Triju Zvaigžņu ordeṇa I pakāpes goda zīmi [10]. Tas apliecina darbinieku sieviešu apzinīgo attieksmi pret darbu, uzticīgu kalpošanu savas valsts augstskolām un augstākās izglītības attīstībai.

Līdz 1913. gadam tikai vīrieši strādāja arī RPI bibliotēkā. 1913. gadā par brīva līguma darbinieci tika pien,emta Marija Paukule, kas bija pirmā RPI bibliotēkas darbiniece sieviete un tajā strādāja līdz 1915. gadam [11]. 100 gadu laikā situācija ir tik l,oti mainījusies, ka bibliotēkās, tostarp RTU Zinātniskajā bibliotēkā, lielākoties strādā sievietes.

Pirmā pasaules kara gados, kad RPI darbojās Maskavā, trūka mācībspēku. Uz Krieviju evakuējās tikai daḷa mācībspēku, bet tie, kas nebija Krievijas pavalstnieki, nedrīkstēja strādāt RPI. Lai aizpildītu vakances, darbā uzaicināja Maskavas augstskolu pedagogus. Piemēram, mineraloǵiju un kristalogrāfiju 1915. gada oktobrī sāka mācìt pazīstamais krievu kristalogrāfs Jurijs Vulfs (1863-1925), kurš tobrīd bija A. Šan,avska Tautas universitātes profesors. Par RPI asistenti tika piennemta vina kolēǵe Olga L Lebedeva (1884-1955), Maskavas Augstāko sieviešu kursu absolvente. Viṇas uzdevums bija gatavot lekcijas un piedalīties tajās līdzās profesoram. Minētos mācībspēkus un vēl citus pien,ēma «uz laiku», t. i., kamēr būs nepieciešams [12]. Olga Leebedeva drīz apprecējās ar ievērojamo kristalogrāfu Alekseju Šubņikovu (1887-1970), kurš toreiz arī strādāja A. Šan,avska Tautas universitātē, un kḷuva par Olgu Šubṇikovu. Viṇa kopā ar vīru izaudzināja trīs bērnus un strādājusi par mācībspēku Urālu Kalnu institūtā, dzīvojusi un veikusi zinātnisko darbu L̦eṇingradā un Maskavā, 1936. gadā O. Šubṇikova aizstāvēja zinātṇu kandidāta disertāciju, bet 1952. gadā - geologijas-mineraloǵijas zinātṇu doktora disertāciju. Viṇu var pieskaitīt pie pirmajām sievietēm zinātniecēm Krievijā [13], taču viṇas vārdu piemin arī Rīgas Tehniskajā universitātē, kas ir Rīgas Politehniskā institūta darba turpinātāja. 


\section{Sievietes - RPI studentes}

Cariskajā Krievijā, kurā toreiz atradās tagadējā Latvijas teritorija, sievietes augstskolās uzṇēma tikai pēc 1917. gada Februāra revolūcijas. Rīgas Politehniskajā institūtā pirmās sievietes tika uzṇemtas Maskavā 1917. gada 1. septembrī, augstskolas evakuācijas laikā. Pirmo studenšu vidū parasti tiek minēta slavenā latviešu k̦īmiksa Paula Valdena (1863-1957) meita Irisa Valdena-Hollo (1899-1983 [14]. Viṇa studēja kīmiju, taču institūts 1918. gada vasarā darbību Maskavā pārtrauca un studentiem bija jāizvēlas, vai turpināt studijas kādā no Krievijas augstskolām, vai atgriezties Latvijā. No Maskavas atgriezās dalı mācībspēku un studentu, arī profesors Pauls Valdens un vinna meita Irisa. RPI èkā Troṇmantnieka, tagadējā Raiṇa bulvārī 19, senākā Baltijas tehniskā augstskola atsāka darbību ar citiem nosaukumiem - Baltijas Tehniskā augstskola (1918 oktobris-1919 janvāris), tad Latvijas Augstskola (1919 februāris-maijs), ko nodibināja boḷševiki, un Rīgas Tehniskā augstskola (1919 jūnijs-jūlijs). Pēc RPI slēgšanas 1919. gada 3. augustā sākās gatavošanās Latvijas Universitātes (1919-1922: Latvijas Augstskolas) atvēršanai septembrī. Irisa Valdena turpināja kīmijas studijas Rīgā minētajās augstskolās un bija studentu sarakstos līdz 1919. gada 31. augustam [15]. Viṇas tēvs un māte aizbrauca uz Vāciju un arī Irisa atstāja Latviju un pievērsās mūzikai, kḷūstot par pedagoǵi. Līdzās I. Valdenai 1917. gada 1. septembrī studijas Ķīmijas fakultātē sāka vēl sešas sievietes: Feiga Bērenšteina, Boḷeslava Manvelova, Alma Mazurs, Liba Svirskaja, Ida Vovsi un Aleksandra Zadurṇickaja, Arhitektūras fakultātē iestājās divas, Komercijas - septiṇas, Lauksaimniecības - četras, Inženieru - trīs un Mehānikas - viena sieviete. Lai gan viṇas visas iestājās Rīgas Politehniskajā institūtā 1. septembrī, pēc studentu sarakstiem Irisa Valdena ir ceturtā sieviete, jo pirms vinas ir reǵistrētas Rīgā dzimušās Feiga Bērenšteina un Jevgēnija Bērziṇa, kā arī Luubova Belousova no Simbirskas guberņas Krievijā [15]. Komercijas nodalıas studente Kristīne Purmale turpināja studijas LU un 1922. gadā ieguva diplomu [16]. Viṇa 1922. gadā tirdzniecības zinātṇu kandidāta diplomu ieguva reizē ar četriem bijušajiem RPI studentiem - Ābramu Dzimitrovski, Tālivaldi Indru, Cēzaru Pētersonu un Jāni Prevaldu [17], kuri studijas bija sākuši krietni vien agrāk nekā K. Purmale. Dažas studentes sāka studijas dažas dienas vēlāk. Viena no viṇām, Zelda Siljans, 1917. gadā sāka ḳīmijas studijas un 1921. gadā ieguva inženiera k̦īmiķa diplomu LU [18]. Vairums toreizējo studenšu nebija dzimušas Latvijā, un par viṇu tālākajām gaitām ziṇu nav.

Interesanti atzīmēt pētījuma gaitā rastās ziṇas par ǵimenēm, no kurām nāca studēt gribošās sievietes, kas apliecina ǵimenē gūto pieredzi par izglītību kā vērtību un motivācijas rašanos. Daḷai pirmo studenšu tēvi bija ieguvuši augstāko izglītību un sekmēja savu meitu vēlmi studēt. 
Piemēram, K̦īmijas nodal̦as studentes Irisas Valdenas tēvs Pauls Valdens un Arhitektūras nodaļas studentes Annas Mareinas tēvs Eliass Mareins bija Rīgas Politehnikuma absolventi ar k̦īmiķa diplomiem. Mehānikas nodal̦as studentes Olgas Švarcas (1. attēls) [19] tēvs Eduards inženiera tehnologa izglītību neieguva Rīgā un strādāja Krievijas pilsētā Vorožā [20].

Arhīvu dokumenti liecina, ka 1917. gada rudenī līdzās minētajām sievietēm studijas Rīgas Politehniskajā institūtā vēlējās sākt vēl dažas jaunietes, taču dažādu iemeslu dēḷ viṇu nodomi nerealizējās. Piemēram, Komercijas fakultātē (nodaḷā) vēlējās studēt Marta Dēḳēna (1896-1945), latviešu pedagoga Kārḷa Dēḳēna meita. 1917. gada 20. jūlijā viṇa uzrakstīja RPI direktoram Paulam Valdenam lūgumu uzn,emt viṇu augstskolā (2. attēls). Lūgumu augstskolas vadītājs akceptēja. Marta Dēḳēna 1915. gadā ar zelta medaḷu bija beigusi Viḷa Olava komercskolu Rīgā un sākusi medicīnas studijas Maskavā, taču viṇas izvēlēto augstskolu slēdza, un viṇa nolēma turpmāk studēt tautsaimniecību. 1917. gada vasaru viṇa pavadīja Rīgā, taču te ienāca vācu armija, M. Dēḳēna uz Maskavu vairs netika un par RPI studenti vinu neieskaitīja. 1919. gada septembrī

1. attēls. Olgas Švarcas lekciju grāmatinas titullapa, 1917.g. [19].

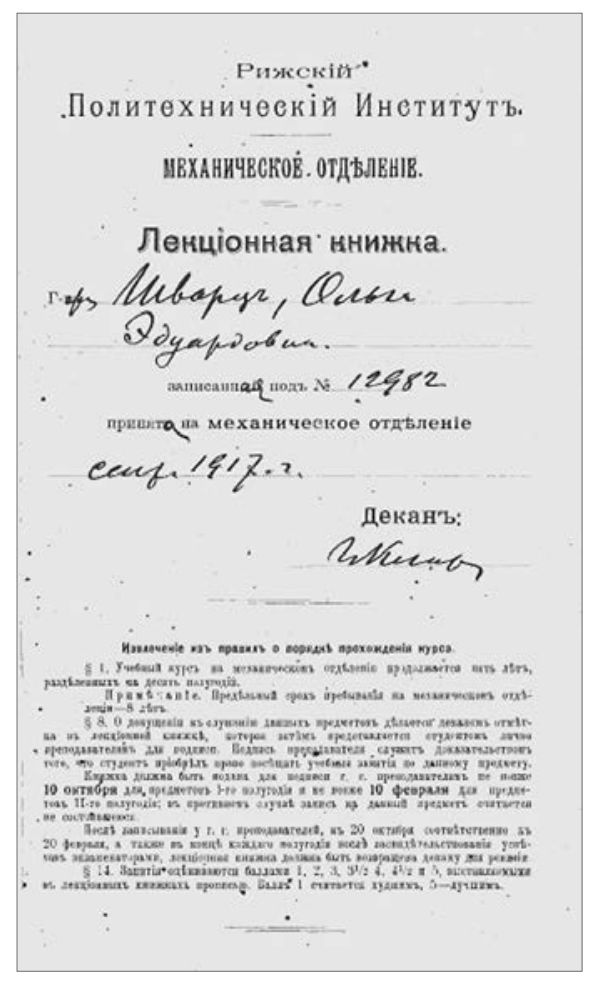

Sievietes Rīgas

Politehniskajā

institūtā

20. gadsimta

sākumā 
viṇa sāka studēt tautsaimniecību Latvijas Augstskolā, vēlākajā Latvijas Universitātē, un 1925. gadā saṇēma augstskolas diplomu [21]. Marta Dēḳēna apprecējās ar inženieri Jāni Jagaru (1892-1970), kurš bija studējis Rīgas Politehniskajā institūtā.

Pēc 19. gadsimtā un 20. gadsimta sākumā notikušajām diskusijām un izmaiṇām politikā un sabiedrībā kopumā viduslaiku tradīcijas augstskolās savu nozīmi zaudēja. Sievietes ieguva līdztiesību ar vīriešiem, un viṇu vēlmei studēt pēc 1917. gadā notikušajām politiskajām izmaiṇām Krievijā nekādi šksēršl,i netika likti. Sākot dibināt 1919. gadā jaunas augstskolas tikko proklamētajā patstāvīgajā valstī Latvijā, nevienam nebija šaubu, ka akadēmiskajā saimē līdzās vīriešiem būs arī sievietes. Atskatoties vēsturē, redzam, ka sievietes devušas nozīmīgu ieguldījumu augstskolu darbībā un dažādās zinātnes nozarēs, tostarp augstskolas pedagoǵijā.

Veicot pētījumu, autore nonāca pie secinājuma, ka sabiedrība sieviešu līdztiesības jautājumus vērtēja dažādi un bija nepieciešami vairāki gadsimti, lai sievietes iegūtu vienlīdzīgas tiesības ar vīrieti. Latvijas teritorijā jau 18. gadsimtā Brālu draudzes kustība sievietes iesaistīja sabiedriskajā dzīvē, kas turpinājās nacionālās atmodas laikā. Rezultātā 20. gadsimta sākumā sievietes sastopam arī Latvijas pirmajā augstskolā: gan kā darbinieces un docētājas, gan kā studentes. Labvēlīgi sieviešu līdztiesības jautājumu ietekmēja sociālie apstākḷi - sieviešu ǵimnāziju atklāšana, iespēja studēt ārvalstu augstskolās. Pētījums atklāj arī gimenes nozīmi sieviešu tieksmē pēc augstākās izglītības un darbības augstskolas vidē.

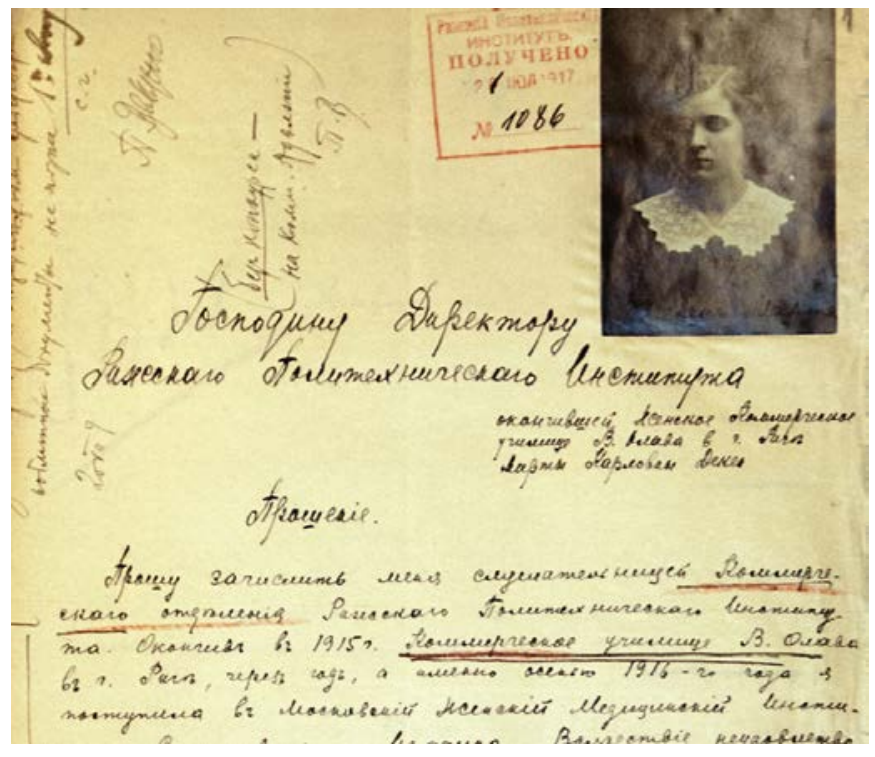

2. attēls. Martas Dēkēēnas lūgums uzñemt vinu RPI Komercijas nodaḷā (fragments), 1917. g. 20. VII [21]. 


\section{AVOTU UN LITERATŪRAS SARAKSTS}

[1] Strautiṇa, I. Brālu draudzes kā religiiskas un sabiedriskas kustības pedagoǵiskais mantojums Vidzemē 18. gadsimtā. Promocijas darba kopsavilkums. Rīga: LU, 2016, 24. lpp.

[2] Kieseritzky, G. Festschrift der Polytechnischen Schule zu Riga zur Feier ihres XVV jährigen Bestehens. Riga: Müller, 1887, S. 59.

[3] Mumenthaler, R. Im Paradies der Gelehrten. Schweizer Wissenschaftler im Zarenreich (1725-1917). Zürich: Hans Rohr Verlag, 1996, S. 542-543.

[4] Kestere, I. Pedagoǵijas vēsture: skola, skolotājs, skolēns. Rīga: Zvaigzne ABC, 2005, 69. lpp.

[5] Zelče, V. Nezināmā: Latvijas sievietes 19. gadsimta otrajā pusē. Rīga: Latvijas Arhīvistu biedrība, 2002, 41., 164. lpp.

[6] Latvijas Valsts vēstures arhīvs (turpmāk LVVA), 7427. f., 13. apr., 1830. l., 2.-25. lp.

[7] LVVA, 7427. f., 13. apr., 30. l., 3.-22.lp.

[8] Lichnij sostav Rizhskovo Politehnizheskavo instituta: 1914/1915 uzhebnij god Riga: E. Plates, 1914, S. 4.

[9] LVVA, 7427. f., 13. apr., 406. l., 10.-28. lp.

[10] Ar Triju zvaigžnu ordeña goda zīmi apbalvoto 12. saraksts. Valdības Vēstnesis, 1934, Nr. 261, 4., 6. lpp.

[11] Lichnij sostav Rizhskovo Politehnizheskavo instituta 1913/14 uzhebnij god. Riga: Mjuller, 1913, S. 7.

[12] LVVA, 7175. f., 1. apr., 253. l., 10., 11., 33., 36. lp.

[13] [Skatīts 2016. g. 20. jūnijā.] Pieejams: baza.vgdru.com/post/1/18697/ p201068.htm

[14] Stradin̦š, J. Pauls Valdens - zinātnieks, rektors, latvietis. Humanitārās un sociālās zinātnes. 8. sēr., 21. sēj., 2013, 25. lpp.

[15] LVVA, 7175. f., 1. apr., 1912. 1., 73., 74., 78., 79. lp.

[16] LVVA, 7427. f., 1. apr., 78. 1., 8.-15. lp.

[17] Rìga. Latvis, 1922, Nr. 127, 3. lpp.

[18] LVVA, 7427. f., 1. apr., 457. 1., 10.-17. lp.

[19] LVVA, 7175. f., 2. apr., 2264. 1., 7.-9.1p.

[20] LVVA, 7175. f., 1. apr., 1912.1., 113.,147.lp.

[21] LVVA, 7427. f., 1. apr., 277. 1., 10.-20. lp. 


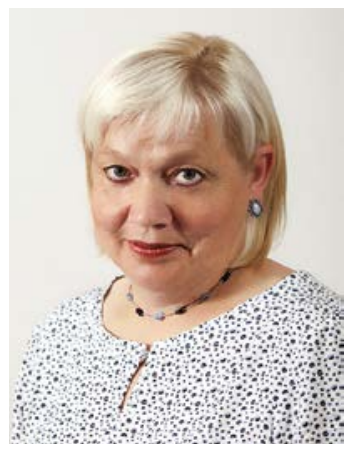

ALĪDA ZIGMUNDE, Dr. paed., was a specialist and Senior Researcher with the Museum of Riga Technical University from 1989-2007, and a Senior Researcher with Riga Technical University from 2007 to 2015. She is currently an Associate Professor with the Institute for Humanities and Head of the Department for Historic Research and Scientific Publications of the Research Centre for Engineering History of Riga Technical University. Her main academic interests include the history of pedagogy in Europe, history of education institutions and private schools, history of pedagogy at universities, history of engineering sciences and of universities.

Address: RTU Research Centre for Engineering History, Kronvalda bulvāris 1, Riga, LV-1010, Latvia

Phone: +37129869642

E-mail: alida.zigmunde@rtu.lv

Alīda Zigmunde

\section{Female Staff at the Riga Polytechnic Institute in the Beginning of the 20th Century}

Riga Polytechnic School, founded in 1862, did not enrol female students. There were only men in the academic staff. In 1896, Riga Polytechnic School was reorganized into Riga Polytechnic Institute. Two years later, Helēna Valdmane was the first woman to have a job with the Institute in the office of the Chancellor. In the beginning of the 20th century, more women joined the personnel. In 1913, Marija Paukule started to work in the Library of Riga Polytechnic Institute. During World War I, Riga Polytechnic Institute was evacuated to Moscow where it renewed the activities in 1915. This was the year when Olga Lebedeva started to work as an assistant. Female students were enrolled from 1st September 1917, but the Polytechnic Institute was closed down in August 1919, therefore none of the female students could finish their studies. Some of them obtained their diploma at other universities, one of them was the University of Latvia in Riga.

Keywords: Female staff, students, docents, Rigas Polytechnic Institute.

Алида Зигмунде

\section{Женщины в Рижском политехническом институте в начале ХХ века}

В 1862 году было основано Рижское политехническое училище, в которое поступить могли только мужчины. Долгие годы женщин не было и в преподавательском составе. В 1896 году училище было преобразовано 
в Рижский политехнический институт, и спустя два года в канцелярию института была принята Хелена Валдмане. Она стала первой женщиной, которая была принята на работу в это учебное заведение. Продолжала работать и в начале 20 -го века, когда в канцелярию института были приняты еще и другие женщины. В библиотеке вуза первая женщина Мария Паукуле начала работать в 1913 году. В преподавательском составе первая женщина появилась лишь в 1915/16 учебном году, в годы эвакуации института в Москву. Это была ассистентка Ольга Лебедева. Первые студентки были приняты 1 сентября 1917 года, но так как Рижский политехнический институт в августе 1919 года был закрыт, то дипломы они не получили. Позже, часть первых студенток получили дипломы других высших учебных заведений, в том числе Латвийского университета.

Ключевые слова: женщины-сотрудницы, студентки, преподавательницы, Рижский политехнический институт. 